\title{
Identifikasi Model Pengelolaan Lahan Kering Dataran Tinggi Berbasis Agroforestri Tradisional di Pulau Timor
}

\author{
Yakobus Pffeferius Edvend Saba $\mathrm{Agu}^{\mathrm{a}}$ dan Eduardus Y. Neonbeni ${ }^{\mathrm{b}}$ \\ ${ }^{a}$ Fakultas Pertanian, Universitas Timor, Kefamenanu, TTU - NTT, Indonesia, email: jechoforester@gmail.com \\ ${ }^{b}$ Fakultas Pertanian, Universitas Timor, Kefamenanu, TTU - NTT, Indonesia, email: ambeni02@ gmail.com
}

\section{Article Info}

\section{Article history:}

Received 21 Desember 2018

Received in revised form 06 Januari 2019

Accepted 20 Januari 2019

DOI:

https://doi.org/10.32938/sc.v4i01.460

\section{Keywords:}

Agroforestri Tradisional

Lahan Kering

Dataran Tinggi

\begin{abstract}
Abstrak
Tujuan diadakannya penelitian ini untuk; (i) mengidentifikasi model pengelolaan lahan kering dataran tinggi berbasis agroforestri tradisional; (ii) mengukur seberapa besar kontribusi pendapatan rumah tangga masyarakat yang diperoleh pada masing-masing model pengelolaan lahan kering dataran tinggi berbasis agroforestri tradisional. Penelitian ini dilaksanakan di Pulau Timor khususnya di kecamatan Miomaffo Barat, Kabupaten Timor Tengah Utara, Nusa Tenggara Timur pada bulan Oktober-Desember 2016 menggunakan metode deskriptif eksploratif dengan teknik pengumpulan data menggunakan teknik observasi, kuesioner, dan wawancara langsung pada tokoh kunci (Qey person). Penentuan sampel dalam penelitian ini berdasarkan peta existing conditions penggunaan lahan yang merupakan hasil overlay data Citra landsat serta data persebaran ekologi agroforestri di pulau Timor. Penentuan responden guna mengetahui kontribusi ekonomi masyarakat ditentukan secara snowball sampling. Hasil penelitian diketahui bahwa terdapat tiga model agroforestri tradisional yang dikembangkan masyarakat di lokasi penelitian yaitu; (a) model agrosilvicultur Kono yang merupakan praktik perladangan menetap dengan komposisi jenis tanaman berkayu (Kehutanan), tahunan dan tanaman semusim; (b) model agrosilvopasture Poan yang merupakan praktik kebun hutan tetap dengan variasi jenis tanaman yang tinggi (Polycultur) serta bentuk pengelolaan yang menyerupai bentuk kebun hutan (Forest Garden) dengan stratifikasi tajuk yang beragam; (c) model silvopastural Suf, merupakan praktik penggembalaan alam pada kawasan padang savana, yang dimanfaatkan sebagai ranch peternakan alami. Analisis kontribusi pendapatan rumah tangga masyarakat diketahui di atas 50\%. Artinya bahwa secara kontribusi ketiga model agroforestri tradisional yang ditemukan berpeluang untuk dikembangkan dengan perlu adanya intervensi intensif dalam hal pengelolaan yang berkelanjutan dengan pertimbangan pada aspek ekologi wilayah, sosial ekonomi serta budaya atau kearifan lokal masyarakat setempat.
\end{abstract}

\section{Pendahuluan}

Optimalisasi lahan kering erat kaitannya dengan konteks sejarah dan budaya bertani di tingkat regional, terutama dalam kaitannya dengan lingkungan sosial para pengguna teknologi dan strategi pemanfaatan lahan (Suradisastra, 2001). Menurut Djogo (1994) agroforestri merupakan bentuk pengembangan pertanian lahan kering yang dapat membantu perbaikan sistem pertanian di daerah kering secara berkelanjutan berdasarkan kearifan lokal masyarakat setempat. Hal senada juga diungkapkan oleh Sabarnurdin dkk, (2011) bahwa praktik agroforestri merupakan salah satu teknologi yang mampu memperbaiki sifat fisik, kimia dan biologi tanah. Selain itu dengan keragaman jenis tanaman pada komunitas agroforestri dipandang sebagai upaya untuk menghindari kegagalan produksi berbasis komoditi tunggal sekaligus menciptakan keseimbangan lingkungan dan keamanan pangan (security foods) yang berkelanjutan.

Kecamatan Miomaffo Barat merupakan salah satu kecamatan di Kabupaten Timor Tengah Utara (TTU) dengan luas wilayah mencapai 199,63 $\mathrm{km}^{2}$ atau 7,48\% (RPJMD, 2011). Berdasarkan rencana tata ruang dan tata wilayah (RTRW) Kabupaten TTU tahun 2018-2038 tentang penetapan kawasan strategi, wilayah kecamatan Miomaffo Barat merupakan salah satu kawasan strategis agropolitan berbasis peternakan, pertanian, tanaman pangan, dan perkebunan. Namun pada kenyataannya budaya pertanian konvensional merupakan langganan teknologi yang paling diminati masyarakat petani hutan di wilayah setempat dengan adanya kebiasaan bertani pada daerah-daerah berbukit dan berlereng curam (> 35\%) dengan kisaran ketinggian > $600 \mathrm{~m}$ dpl.

Berdasarkan hasil penelitian Dako (2010), di daerah Timor dijelaskan bahwa kehidupan sosial ekonomi masyarakat yang berada di sekitar kawasan hutan lindung Mutis Timau (termasuk wilayah Miomaffo Barat) masih jauh dari harapan dengan tingkat pendapatan penduduk sebesar Rp1.836.797/kapita/tahun yang dikategorikan miskin, dengan keadaan defisit lahan pertanian seluas 140,76 ha atau $0,34 \mathrm{ha} / \mathrm{kk}$, defisit pakan ternak sebesar $1.420 \mathrm{~kg} / \mathrm{hari}$, defisit produksi pangan sebesar 13.717,2 kg, defisit kebutuhan pangan sebesar $45.581 \mathrm{~kg} / \mathrm{tahun}$ dengan kondisi kawasan yang telah mengalami deforestasi dan degradasi lahan. Berdasarkan hal tersebut diketahui bahwa upaya pembangunan ekosistem lahan kering yang berkelanjutan di wilayah pulau Timor secara umum memerlukan intervensi intensif berdasarkan existing conductions pengelolaan lahan baik berupa pertimbangan aspek ekologi, sumberdaya lahan, sosial ekonomi, budaya (kearifan lokal) dalam ritus tani. Hadirnya model sistem pertanaman agroforestri yang adalah suatu bentuk sistem pengolahan lahan berkelanjutan yang ditujukan untuk meningkatkan produktivitas lahan dengan mengkombinasikan antara tanaman pertanian dan tanaman kehutanan dan/atau hewan secara simultan atau berurutan dalam unit lahan yang sama dan penerapan teknologi yang sesuai dengan keadaan sosial budaya masyarakat setempat merupakan hal yang penting untuk dipikirkan dan untuk dikembangkan (Ukrani dan Jain, 2010).

Penelitian ini bertujuan untuk; (i) mengidentifikasi model pengelolaan lahan kering dataran tinggi berbasis agroforestri tradisional yang dipraktikkan oleh masyarakat di kecamatan Miomaffo Barat; (ii) mengukur seberapa besar kontribusi pendapatan rumah tangga masyarakat (KPC) yang diperoleh pada masing-masing model pengelolaan lahan berbasis agroforestri tradisional di kecamatan Miomaffo Barat.

\section{Metode}

Penelitian ini dilaksanakan di Pulau Timor khususnya di Kecamatan Miomaffo Barat, Kabupaten TTU, Nusa Tenggara Timur pada bulan OktoberDesember 2016 dengan pertimbangan pada letak ketinggian tempat lokasi penelitian yang merupakan daerah dataran tinggi (Up land) dengan ketinggian tempat $\geq 600 \mathrm{Mdpl}$, intensitas curah hujan yang rendah (1.300 -1.500 mm/tahun) serta jumlah hari hujan (70-75 hari) dilokasi penelitian berdasarkan data BPS Kabupaten TTU (Saba Agu, 2017) pada Gambar 1.

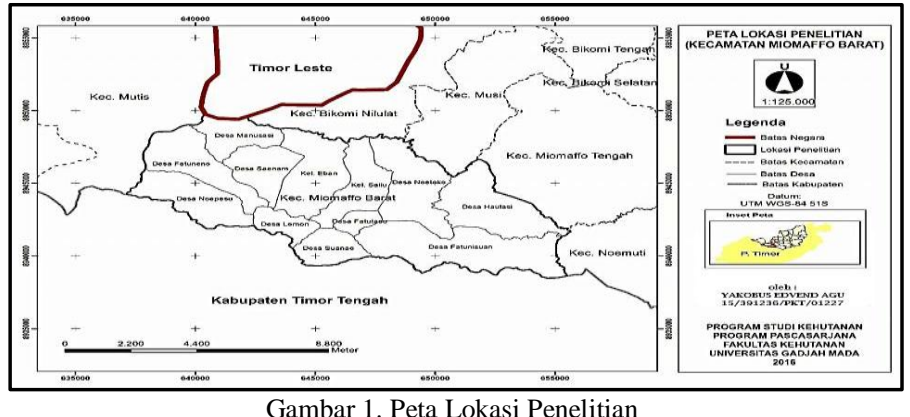

a. Teknik Pengumpulan Data

Penelitian ini menggunakan metode deskriptif eksploratif dengan teknik pengumpulan data menggunakan teknik observasi, kuesioner, dan wawancara langsung pada tokoh kunci (Qey person). Penentuan sampel dalam penelitian ini berdasarkan peta existing conditions penggunaan lahan yang merupakan hasil overlay data Citra landsat serta data persebaran ekologi agroforestri di pulau Timor. Penilaian kontribusi ekonomi masyarakat pada berbagai model agroforestri tradisional diperoleh dengan menggunakan teknik kuesioner dan wawancara (interview) langsung yang bersifat terstruktur. Penentuan responden guna mengetahui kontribusi ekonomi masyarakat ditentukan secara snowbal sampling dengan ketentuan responden merupakan masyarakat tani hutan pemilik lahan (kebun) yang menerapkan usaha tani berbasis model agroforestri tradisional dengan kriteria penentuan berdasarkan aspek luasan kepemilikan lahan. Responden yang ditentukan dalam penelitian ini berjumlah 10 orang untuk masing-masing model penggunaan lahan berbasis agroforestri tradisional yang ditemukan di lokasi penelitian.

\section{b. Analisis Data}

Analisis data yang digunakan dalam penelitian ini merupakan analisi deskriptif kualitatif serta analisis kontribusi usaha tani agroforestri. Penilaian kontribusi ekonomi pendapatan rumah tangga pada berbagai model agroforestri tradisional dianalisis dengan menggunakan persamaan (Gumelar, 2014) sebagai berikut:

$$
K P C=\frac{P C}{P T R} \times 100 \%
$$

Keterangan:

$\mathrm{KPC}=$ Kontribusi Usaha Tani Agroforestri

$\mathrm{PC} \quad=$ Total Pendapatan Usaha Pertanian berbasis Agroforestri

PTR = Pendapatan Total Rumah tangga

Jika nilai $\mathrm{KPC}>$ di atas $50 \%$, maka model pengelolaan lahan yang diterapkan oleh masyarakat berkontribusi bagi pendapatan rumah tangga 
masyarakat dan layak untuk diusahakan, namun apabila nilai KPC di bawah 50\% maka model penggunaan lahan yang diterapkan oleh masyarakat tidak memberikan kontribusi bagi pendapatan rumah tangga masyarakat dan tidak layak untuk diusahakan. Penelitian ini dibatasi pada unit lahan yang dikembangkan dengan model-model agroforestri tradisional yang berada pada daerah dataran tinggi (Up land) dengan pertimbangan pada komposisi dan jenis komoditi yang dibudidayakan, pola tanam serta kontribusi ekonomi masyarakat.

\section{Hasil dan Pembahasan}

\subsection{Keadaan Umum Lokasi Penelitian}

Wilayah pulau Timor secara umum termasuk kecamatan Miomaffo Barat memiliki persebaran tipe iklim D (Semi arid) berdasarkan Schmidth dan Ferguson dengan mengacu pada perhitungan jumlah dan intensitas hari hujan dengan intensitas curah hujan yang rendah sekitar 1.300-1.500 mm/tahun serta jumlah hari hujan yang hanya mencapai 70-75 hari/tahun. Keadaan curah hujan rata-rata antara $500-3000 \mathrm{~mm} /$ tahun dengan rata-rata suhu maksimum/tahun mencapai $31.6{ }^{\circ} \mathrm{C}$ dan rata-rata suhu minimum mencapai $21.5^{\circ} \mathrm{C}$. Curah hujan dan suhu udara sebagai unsur iklim merupakan faktor lingkungan penentu perencanaan pertanian terutama pengaruhnya terhadap pertumbuhan dan produktivitas tanaman. Selain itu pada aspek keadaan lahan di lokasi penelitian secara umum memiliki keragaman formasi lahan yang cukup tinggi yang didominasi wilayah pegunungan, daerah perbukitan, teras dan dataran (Saba Agu, 2017).

Luas wilayah administrasi kecamatan Miomaffo Barat mencapai 199,63 $\mathrm{km}^{2}$ dengan luas areal pertanian lahan kering (functional dry land) mencapai $6.193 \mathrm{~km}^{2}$ (BPS Kab. TTU, 2016). Aspek sumberdaya lahan umumnya masih merupakan wilayah yang secara tradisional dipengaruhi oleh hubungan kerajaan tradisional. Salah satu implikasi dasarnya ialah bahwa sistem pemilikan tanah bersifat tradisional, dimana tanah berada di dalam pengaruh atau kekuasaan raja atau keluarga besar dan anggota masyarakat adalah pengguna. Aspek budidaya dalam ritus tadi masyarakat di lokasi penelitian cenderung menghadirkan api pada unit lahan atau kebun mereka mulai dari yang sangat terkendali sampai pada kegiatan pembakaran yang relatif tidak terkendali di samping menerapkan praktik ladang berpindah dengan tanpa mempertimbangkan daur masa bera.

Praktik tebas bakar umumnya dilakukan sebelum musim penghujan, dan hal ini dianggap masyarakat sangat bermanfaat dalam usaha tani lahan kering, karena dapat menghemat waktu dan tenaga sekaligus membantu upaya mendaur hara secara cepat serta dapat memicu terjadinya proses suksesi lahan. Aspek biofisik persebaran lahan di kecamatan Miomaffo Barat terbentuk dari batuan lempung dengan topografi pegunungan yang curam $1^{0}-40^{\circ}$ dan keadaan kelas lereng yang mencapai $26-40 \%$ (Curam) dengan solum tanah yang tipis $(\leq 25$ $\mathrm{Cm}$ ). Keadaan tutupan lahan di kecamatan Miomaffo Barat secara umum didominasi oleh semak belukar, setelah itu hutan lahan kering sekunder, hutan lahan kering campuran, serta padang savana yang diperuntukkan sebagai ranch peternakan tradisional.

\subsection{Ekologi Agroforestri Tradisional Lahan Kering Dataran Tinggi}

Masyarakat Atoin Meto atau orang Dawan sebutan untuk orang Timor merupakan suku asli yang mendiami pulau Timor. Orang Dawan pada awalnya adalah komunitas nomaden, menggembalakan ternak secara berpindah-pindah (kerbau dan sapi) di pinggir hutan sekitar sumber air. Struktur tatanan kehidupan yang demikian menghasilkan suatu bentuk interaksi dan pola komunitas yang erat antara masyarakat Atoin Meto dengan alam (pohon, air dan batu) serta ternak sebagai tujuan pemenuhan kebutuhan hidup, yang berdampak pada munculnya beragam model pengelolaan lahan yang dipraktikkan oleh masyarakat petani hutan di pulau Timor secara umum hingga saat ini (Gambar 2).

Berdasarkan hasil penelitian diketahui kondisi ekologi agroforestri tradisional lahan kering dataran tinggi di lokasi penelitian sangat bervariasi yang dipengaruhi oleh keadaan iklim, topografi, sebaran penduduk yang membentuk unit-unit pengelolaan pertanian lahan kering, hal pemenuhan ekonomi rumah tangga serta keadaan wilayah yang masih merupakan wilayah moderat dalam sebaran vegetasi. Secara umum bentuk ekologis agroforestri yang ditemukan di lokasi penelitian (Gambar 3) adalah sebagai berikut:

a) Model Agrosilvicultur Kono

b) Model Agrosilvopasture Poan

c) Model Silvopastur Suf

Sebaran ekologi agroforestri pada lokasi penelitian dapat dijumpai pada berbagai kelas ketinggian tempat mulai dari ketinggian $653 \mathrm{Mdpl}-1.763 \mathrm{Mdpl}$ dan merupakan bagian yang tidak terpisahkan dari distribusi persebaran penduduk yang membentuk unit-unit pemukiman di masa lalu hingga saat ini.

\subsection{Model Agroforestri Tradisional Dataran Tinggi di Pulau Timor}

Berdasarkan karakteristik kearifan lokal masyarakat di lokasi penelitian dalam hal pengelolaan lahan dengan pertimbangan aspek komposisi jenis tanaman serta pola pengaturan tanaman di lahan diketahui beberapa model pengelolaan lahan kering dataran tinggi berbasis agroforestri tradisional yang telah dikembangkan serta memiliki tingkat adopted yang tinggi (Gambar 4, Gambar 5 dan Gambar 6) diantaranya:

\section{a). Model Silvopastur Suf}

Model Silvopastur Suf merupakan praktik penggembalaan alam di pulau Timor yang mendominasi pada daerah dataran tinggi dengan kisaran ketinggian antara 1.353-1.763 mdpl (Gambar 4). Ekologi kawasan Suf menyerupai praktik model silvopastur (agroforestri modern) yang dikembangkan pada kawasan padang savana yang bertumbuh pohon, semak dan atau herba yang menyebar, terisolasi satu dengan yang lainnya yang dimanfaatkan sebagai ranch pemeliharaan ternak (Babi, Kuda dan Sapi) secara lepas. Penentuan dan penetapan kawasan atau ranch Suf oleh raja atau temukung/tobe (Kepala Suku) yang didasarkan pada jumlah suku atau klan yang mendiami wilayah tersebut serta jumlah populasi ternak yang terdapat pada wilayah atau kampung dengan pertimbangan pada hasil musyawarah bersama.
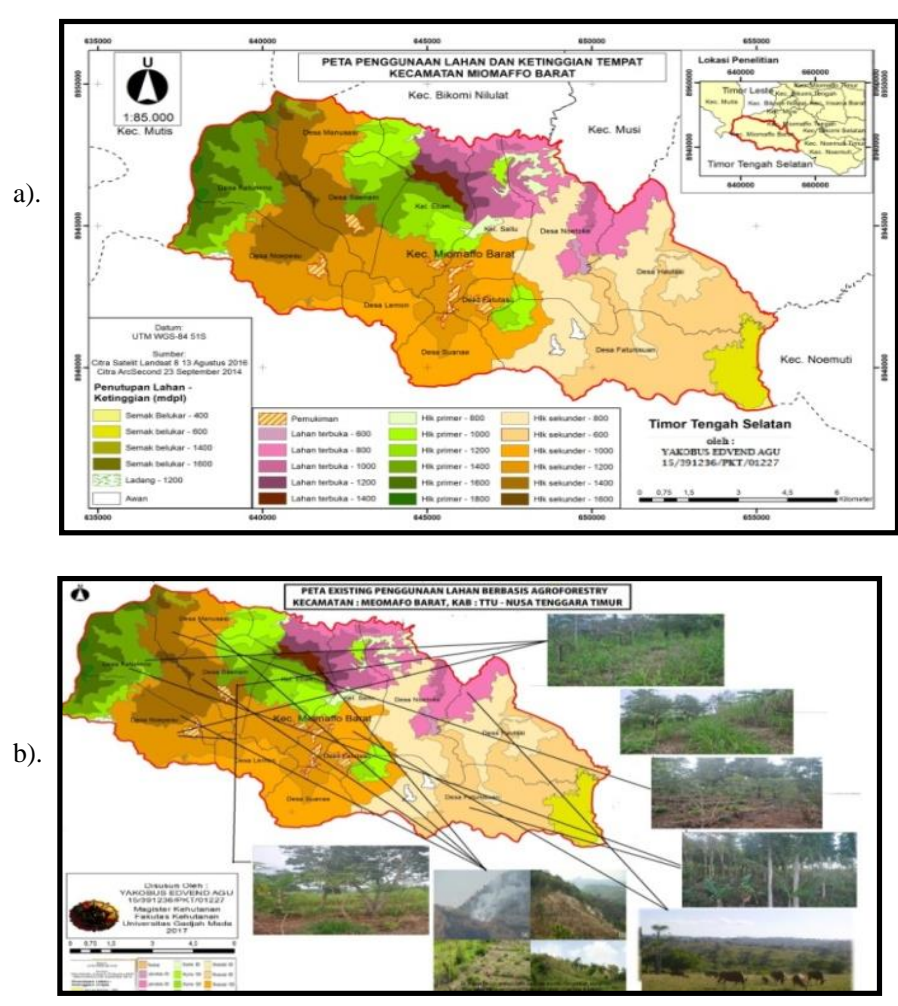

Gambar 2. (a dan b). Peta Existing Condition Penggunaan Lahan Masyarakat Miomaffo Barat

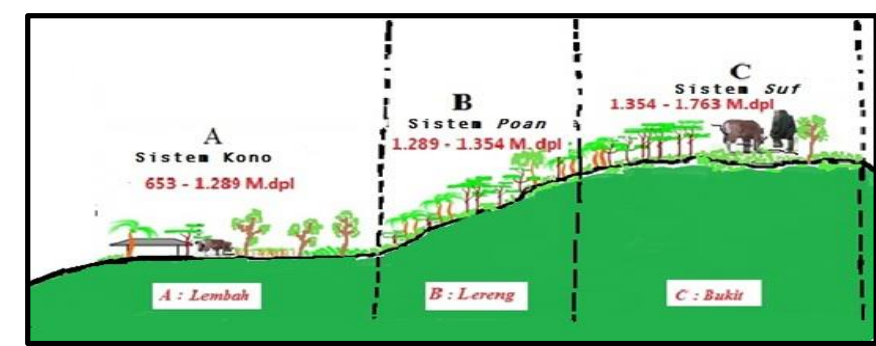

Gambar 3. Lanscape Ekologi Agroforestri Tradisional Lahan Kering Dataran Tinggi

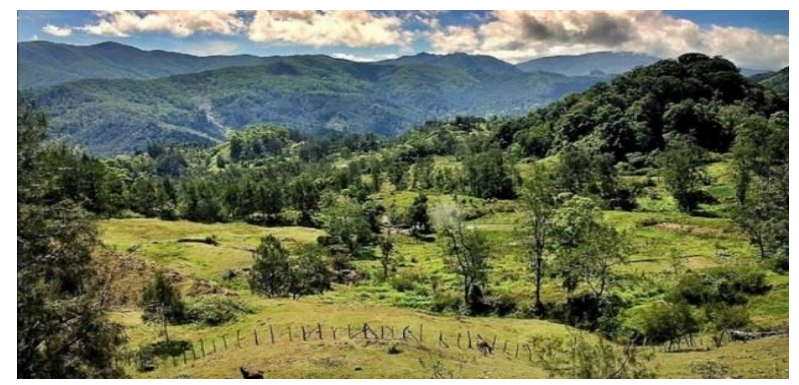

Gambar 4. Kawasan Ranch Silvopastur Suf

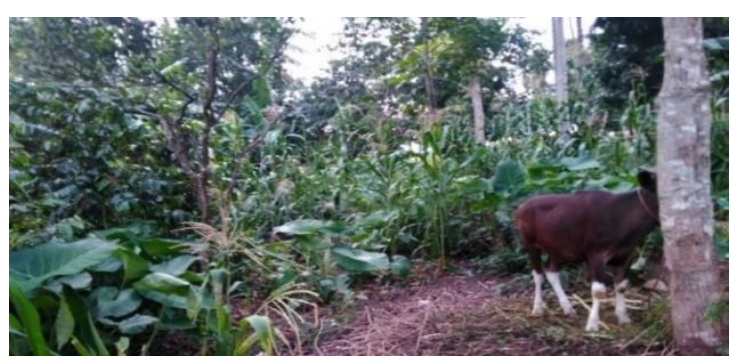

Gambar 5. Model Pengelolaan Agrosilvopasture Poan 


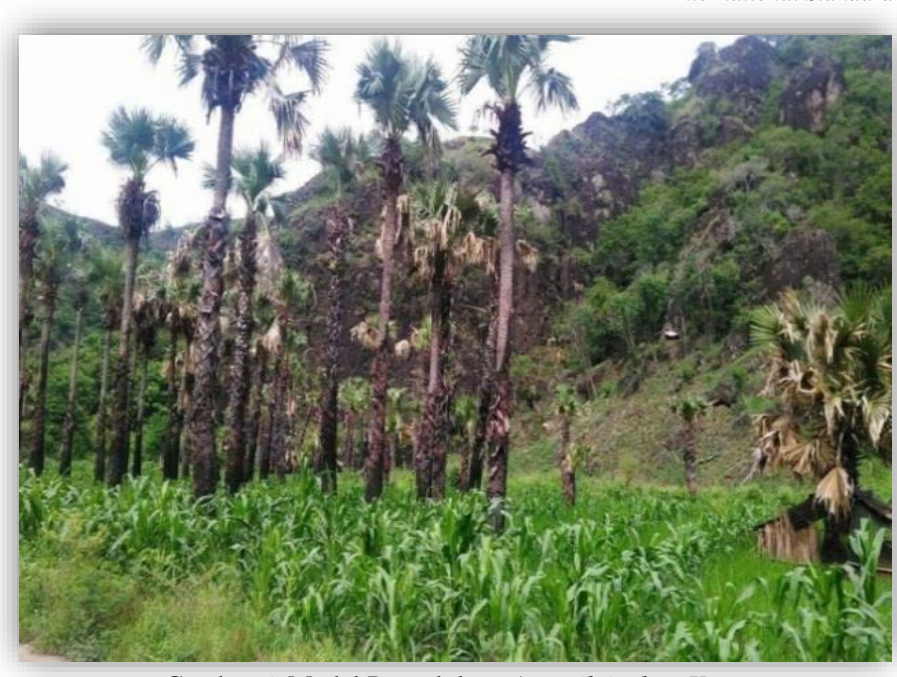

Gambar 6. Model Pengelolaan Agrosilvicultur Kono

Tabel 1. Komponen Penyusun Model Silvopastur Suf

\begin{tabular}{|c|c|c|c|}
\hline \multicolumn{3}{|c|}{ Komponen Penyusun } & \multirow{3}{*}{ Manfaat } \\
\hline & Nama Lokal & Nama Binomial & \\
\hline \multicolumn{3}{|c|}{ Tanaman Berkayu : } & \\
\hline 1 & Атрири & Eucalyptus urophylla & Konservasi \\
\hline 2 & Mahoni & Swietenia macrophylla L & Ekonomi \& Konservasi \\
\hline 3 & Aijao / Cemara gun & ung Casuarina junghuniana & Ekonomi \& Konservasi \\
\hline 4 & Gewang & Corypha gebanga & Ekonomi \& Konservasi \\
\hline 5 & Beska / Kabesak & Acacia leucophloea & Ekonomi \& Konservasi \\
\hline 6 & Akasia & Acacia auriculiformis & Ekonomi \& Konservasi \\
\hline \multicolumn{3}{|c|}{ Pakan Ternak: } & \\
\hline \multirow{6}{*}{$\begin{array}{l}2 \\
3 \\
4 \\
5\end{array}$} & $\begin{array}{l}\text { Kingres / Rumput } \\
\text { Gajah }\end{array}$ & $\begin{array}{l}\text { Pennisetum purpureum } \\
\text { Sesbania grandiflora }\end{array}$ & Ekonomi \& Konservasi \\
\hline & Gala-gala / Turi & Leucaena leucocephala & Ekonomi \& Konservasi \\
\hline & Lamtoro Gun & Acacia villosa & Ekonomi \& Konservasi \\
\hline & Pates & Zizyphus mauritiana & Ekonomi \& Konservasi \\
\hline & \multicolumn{2}{|c|}{ 5. Kabuka, Kom atau } & Ekonomi \& Konservasi \\
\hline & Bidara & Jatropha gossypifolia & \\
\hline 6 & Pankase & Bauhinia purpurea $L$. & Ekonomi \& Konservasi \\
\hline & Hau boela / Pohon & & Ekonomi \& Konservasi \\
\hline & Dаип Кири-Кири & Ficus $S p$ & \\
\hline 8 & Beringin & Ceiba petandra & Ekonomi \& Ko \\
\hline \multirow[t]{2}{*}{9.} & Kapok & & Ekonomi \& Kol \\
\hline & \multicolumn{2}{|c|}{ Tanaman Semusim } & \\
\hline & Jagung & Zea mays & Ekonomi \\
\hline & Singkong & Manihot utilissima & Ekonomi \\
\hline 3. & Uwi & Dioscorea balcanica & Ekonomi \\
\hline t. & Gembili & Dioscorea asculenta. $L$ & Ekonomi \\
\hline & Kacang Merah & Vigna angularis & Ekonomi \\
\hline \multirow{2}{*}{\multicolumn{2}{|c|}{ j. Kacang Tanah }} & Arachis hypogaea & Ekonomi \\
\hline & & Ternak: & \\
\hline & Bijae / Sapi Bali & Bos taurus sp & Ekonomi \\
\hline & Bikase / Kuda & Equus caballusL. & Ekonomi \\
\hline & Faif / Babi & Sus scrofa & Ekonomi \\
\hline
\end{tabular}

Komposisi jenis tanaman penyusun model Silvopastur Suf (Tabel 1) terdiri atas jenis tanaman kehutanan, pakan ternak, dan tanaman semusim serta ternak dengan jenis tanaman yang mendominasi yaitu Атрири (Eucalyptus urophylla) dan Cemara gunung (Casuarina equisetifolia).

Permasalahan yang ditemukan pada pengembangan model Silvopastur Suf di lokasi penelitian adalah:

1) Produktivitas pakan yang rendah dengan sistem budidaya yang bersifat terbatas hanya memanfaatkan jenis tanaman yang tumbuh secara persebaran alami.

2) Daya tampung dan daya dukung lahan yang rendah.

3) Luasan areal budidaya pakan yang sangat terbatas dengan luasan terbesar yaitu $400 \mathrm{~m}^{3}$.

4) Umumnya masih bersifat tradisional dalam skala konsumtif dengan lebih mengejar pemenuhan ekonomi rumah tangga semata.

Pertimbangan carrying capacity, pemilihan jenis pakan, serta ruang jelajah ternak (roaming) menjadi penting sebagai tindakan intervensi yang mengarah pada penerapan rezim silvopasture intensif sebagai upaya peningkatan kontribusi ekonomi masyarakat serta mengembalikan predikat daerah Timor sebagai daerah lumbung ternak nasional. Penerapan pola integrasi ternak pada model agroforestri memiliki nilai yang lebih, di samping meningkatkan pendapatan ekonomi juga menjamin keberlanjutan lahan dengan perlakuan konservasi. Beberapa pola pengelolaan model Suf yang tampak pada lokasi penelitian diantaranya: a) Pola ranch penggembalaan alami yaitu; masyarakat menggembalakan ternak, baik ternak sapi, kuda serta babi secara lepas pada satu hamparan lahan luas di bawah tegakkan ampupu (Eucalyptus urophylla) serta cemara gunung (Casuarina Junghuniana) dengan sumber pakan yang berasal dari rumput yang tumbuh secara alami pada kawasan ranch suf.

b) Pola intervensi semi intensif yaitu; pemeliharaan ternak dengan memasukkan ternak pada kebun milik masyarakat dengan cara diikat tanpa dikandangkan kemudian masyarakat memberikan pakan. Sumber pakan diperoleh dengan cara mengarit rumput yang tumbuh secara persebaran alami maupun yang di budidaya pada kebun masyarakat sendiri.

c) Pola Intervensi Intensif yaitu; pemeliharaan ternak dengan cara dikandangkan atau paronisasi. Jenis ternak yang dikandangkan yaitu jenis ternak jantan. Pada sistem ini masyarakat mengupayakan pakan baik kelompok HMT dan RMT pada lahan mereka. Pada sistem ini masyarakat pada umumnya hanya mampu memelihara satu ekor ternak sapi dalam kisaran waktu setahun hingga dua tahun hal ini dikarenakan keterbatasan lahan garapan, tenaga, serta produktivitas pakan yang rendah.

\section{b). Model Agrosilvopasture Poan}

Istilah Poan dalam praktik usaha tani bagi masyarakat Dawan di wilayah Miomaffo diistilahkan sebagai praktik kebun tetap dengan variasi jenis tanaman yang tinggi (Polycultur) menyerupai bentuk kebun hutan (Forest Garden) yang mendominasi pada kisaran ketinggian tempat antara $1.289-1.354 \mathrm{Mdpl}$ Gambaran ekologi kebun Poan serta bentuk pengelolaan yang dipraktikkan masyarakat di lokasi penelitian secara umum menyerupai praktik mode agrosilvopasture (agroforestri modern) dengan bentuk stratifikasi tajuk yang beragam serta jenis tanaman yang di budidaya sangat kompleks (Polycultur). Masyarakat dalam penerapan pengelolaan lahan berbasis model agrosilvopasture Poan, beranggapan bahwa model tersebut merupakan lumbung pangan yang tersedia di kebun dengan jenis komoditi yang di budidaya sangat beragam serta mampu memberikan jaminan ketersediaan pangan saat masalah gagal panen atau rawan pangan tiba. Hal aturan pengelolaan kebun Poan pada lokasi penelitian dimana masyarakat tidak diperbolehkan menggunakan sistem tebas bakar sesuai kesepakatan adat yang berlaku pada wilayah setempat dan apa bila kesepakatan ini dilanggar maka masyarakat yang ketahuan akan dikenakan sanksi adat. Sanksi adat yang diterapkan beragam tergantung kesepakatan para temukung/tobe (kepala suku) atau pada wilayah tersebut. Komposisi penyusun model kebun Agrosilvopasture Poan pada lokasi penelitian dapat dilihat pada Tabel 2

Tabel 2. Komposisi Jenis Tanaman Penyusun Model Agrosilvopasture Poan $\frac{\text { Tabel 2. Komposisi Jenis Tanaman Penyusun Model Agrosilvopasture Poan }}{\text { Komponen Penyusun }}$

\begin{tabular}{|c|c|c|c|}
\hline \multicolumn{3}{|c|}{ Komponen Penyusun } & \multirow{3}{*}{ Manfaat } \\
\hline & Nama Lokal & Nama Binominal & \\
\hline \multicolumn{3}{|c|}{ Tanaman Berkayu : } & \\
\hline 1. & Haumeni/Cendana & Santalum album & Konservasi \\
\hline 2. & Атрири & $\begin{array}{l}\text { Eucalyptus } \\
\text { urophylla }\end{array}$ & Konservasi \\
\hline 3. & Mahoni & $\begin{array}{l}\text { Swietenia } \\
\text { macrophylla L }\end{array}$ & Konservasi \\
\hline 4. & $\begin{array}{l}\text { Aijaol } \\
\text { gunung }\end{array}$ & $\begin{array}{l}\text { Casuarina } \\
\text { junghuniana }\end{array}$ & Konservasi \\
\hline 5. & Jati putih & Gmelina arborea & Konservasi \\
\hline 6. & Kemiri & $\begin{array}{l}\text { Aleurites } \\
\text { moluccanus }\end{array}$ & Konservasi \\
\hline 7. & Waru & $\begin{array}{l}\text { Habiscus } \\
\text { macrophyllus }\end{array}$ & Konservasi \\
\hline 8. & Ulabe/ Kesambi & Schleichera oleosa & Konservasi \\
\hline 9. & Kapok & Ceiba petandra & Konservasi \\
\hline $\begin{array}{r}10 . \\
\mathrm{Ta}\end{array}$ & $\begin{array}{l}\text { Beringin } \\
\text { aman Tahunan : }\end{array}$ & Ficus sp & Konservasi \\
\hline 1. & Kopi & Coffea arabica & Ekonomi \\
\hline 2. & Jeruk Purut & Citrus hystrix & Ekonomi \\
\hline 3. & Apel & Malus domestica & Ekonomi \\
\hline 4. & Alpukat & Persea Americana & Ekonomi \\
\hline 5. & Nanas & Ananas comosus & Ekonomi \\
\hline 6. & Sirih & Piter betle & Ekonomi \\
\hline 7. & Pinang & Areca catechu & Ekonomi \\
\hline 8. & Pepaya & Carica papaya & Ekonomi \\
\hline 9. & Srikaya & Annona aquamosa & Ekonomi \\
\hline 10. & Pisang Kepok & Musa paradisiaca $\mathrm{L}$ & Ekonomi \\
\hline
\end{tabular}

Tanaman Semusim :

1. Jagung

2. Kacang Merah

3. Jeruk Purut

4. Kacang Turi

5. Wortel

6. Kacang Tanah

7. Labu Kuning

8. Labu Jepang

9. Bawang Merah

10. Bawang Putih 
11. Bawang Daun

12. Talas

13. Kentang

14. Ubi Jalar

15. Singkong

16. Gembili

17. Uwi

18. Porang

$\begin{array}{ll}\text { Allium fistulosum } & \text { Ekonomi } \\ \text { Caladium bicolor } & \text { Ekonomi } \\ \text { Solanum tuberosum } & \text { Ekonomi } \\ \text { Ipomoea batata } & \text { Ekonomi } \\ \text { Manihot utilissima } & \text { Ekonomi } \\ \text { Dioscorea esculenta } & \text { Ekonomi } \\ \text { Dioscorea balcanica } & \text { Ekonomi } \\ \text { Amorphophallus } & \text { Ekonomi } \\ \text { muelleri } & \end{array}$

Pakan Ternak

\section{Gajah/}

Pennisetum purpureum

Gala-galal Turi

3. Lamtoro

4. Kaliandra

5. Gamal

Ternak :

1. Bijae/Sapi

2. Bikase/Kud

3. Faif/Babi

Sesbania grandiflora

Leucaena

leucocephala

Caliandra

Gliricidia sepium

Bos taurus $\mathrm{sp}$

Eqqus caballus L

Sus scrofa

\section{Ekonomi \& Konservasi}

Ekonomi \& Konservasi Ekonomi \& Konservasi

Ekonomi \& Konservasi Ekonomi \& Konservasi

Gambaran karakteristik pengelolaan model kebun Poan yang tampak pada lokasi penelitian yaitu:

1. Variasi jenis tanaman tinggi (Polikultur),

2. Stratifikasi tajuk tinggi,

3. Ketersediaan unsur hara relatif lebih tinggi,

4. Pola penggunaan lahan bervariasi berdasarkan pertimbangan kondisi agro ekologi lakan/kebun,

5. Model pertanian menetap,

6. Berbentuk kebun hutan (Forest garden).

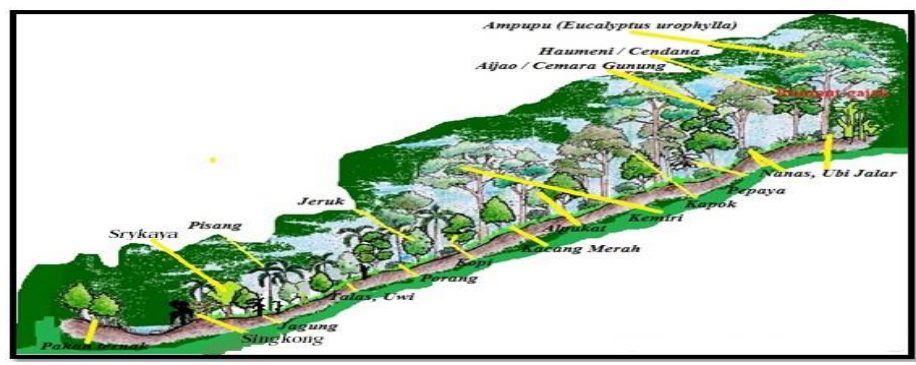

Gambar 7. Profil Kebun Poan Pada Daerah Dataran Tinggi Kecamatan Miomaffo Barat

Pengembangan kebun Poan oleh masyarakat di Timor secara umum dinilai sangat penting dimana hadirnya kebun Poan tidak hanya dipahami sebatas unit lahan yang terpisah tetapi lebih dari pada itu masyarakat juga meyakini keberadaan kebun Poan sebagai lumbung pangan kehidupan mereka, yang selalu tersedia di kebun serta memberikan jaminan ketersediaan pangan saat masalah gagal panen atau rawan pangan tiba. Diakui masyarakat juga bahwa dengan praktek model Poan tanaman yang di budidaya mereka tahan terhadap gangguan hama penyakit. Namun kenyataan yang dijumpai masyarakat petani hutan pada sebagian besar wilayah ini cenderung menerapkan usaha tani yang masih bersifat konsumtif semata dengan tanpa adanya perubahan paradigma kearah yang lebih modern dengan luasan kepemilikan lahan yang minim atau di bawah 1 ha Beberapa pola praktik pengelolaan lahan pada model Agrosilvopasture Poan yang temukan di lokasi penelitian yaitu:

a) Alley Cropping

Bentuk pengelolaan pola Alley Cropping yang dijumpai dimana masyarakat cenderung menggunakan jenis tanaman Pates, Kaliandra, Nanas, Lamtoro maupun Rumput Gajah sebagai pembatas larikan antar tanaman. Tanaman ini umumnya digunakan masyarakat sebagai tanaman penguat teras dalam upaya pengurangan splash erosi lahan. Selain itu Sebagai penutup lahan masyarakat juga mengupayakan jenis leguminosae misalnya jenis kacangkacangan. Pada lorong atau gang-gang tersebut masyarakat menanam kopi, jagung, labu, singkong serta berbagai jenis tanaman semusim lainnya.

\section{b) Pola Tiga Tingkat}

Pertimbangan pengelolaan pola tiga tingkat pada model Poan oleh masyarakat di lokasi penelitian adalah berdasarkan letak kebun masyarakat dengan mempertimbangkan aspek keadaan tingkat lereng atau kelas kemiringan lahan. Secara umum gambaran pengelolaan pola tiga tingkat serta komposisi jenis tanaman yang diupayakan masyarakat dapat dilihat pada Tabel 3.

\section{c). Model Agrosilvicultur Kono}

Istilah Kono bagi masyarakat Dawan di lokasi penelitian merupakan praktik perladangan menetap dengan komposisi jenis tanaman penyusun pada unit lahan (Kebun) yaitu jenis tanaman berkayu (Kehutanan), tahunan dan tanaman semusim yang mendominasi pada wilayah dataran tinggi (Up Land) dengan kisaran ketinggian tempat antara 653-1.289 M dpl pada daerah lembah di dataran tinggi yang keadaan solum tanahnya tipis dan banyak terdapat batubatuan serta semak belukar dan ilalang. Hal yang tampak pada pengelolaan model Kono menyerupai model pengelolaan Agrosilvicultur (Agroforestri modern) dengan jenis tanaman yang di budidaya bersifat terbatas pada jenis-jenis tertentu yang tidak membutuhkan waktu intensif dalam perawatannya serta belum adanya pertimbangan pengaturan lahan secara tepat. Aspek budidaya jenis tanaman kehutanan masih sangat rendah dimana masyarakat masih dominan memanfaatkan jenis tanaman kehutanan yang tumbuh dari permudaan alami. Komposisi jenis tanaman yang ditemukan pada model Agrosilvicultur Kono dapat dilihat pada Tabel 4

Tabel 3. Jenis Tanaman Pola Tiga Tingkat Pada Kebun Poan

\begin{tabular}{clc}
\hline Tingkat & Jenis Tanaman & Letak \\
I. & $\begin{array}{l}\text { Ampupu, Cemara, Lamtoro, Gmelina, } \\
\text { Gamal, Rumput gajah, Kemiri, } \\
\text { Gamal, Rumput gajah. }\end{array}$ & Bukit \\
& Jagung, Kacang Merah, Jeruk Purut, & \\
& Kacang Turi, Wortel, Kacang Tanah, & \\
II. & Labu Kuning, Labu Jepang, Gembili, \\
& Kopi, Jeruk Purut, Apel, Alpukat, & Lereng \\
& Nanas, Pepaya, Srikaya, Singkong. & \\
\hline & Sirih, Pinang, Rumput Gajah, Turi, & \\
III. & Porang, Pisang, Bawang merah, & Lembah \\
& Bawang Putih, Bawang Daun, Talas, & \\
& Kentang, Ubi Jalar, Ternak. &
\end{tabular}

Praktik usaha tani yang nampak pada model Kono di lokasi penelitian dimana jenis tanaman semusim (Jagung dan Padi) lebih mendominasi. Bagi masyarakat setempat budidaya tanaman semusim (Padi dan Jagung) tidak mungkin dilakukan secara terus menerus mengingat input yang dibutuhkan sangat tinggi sehingga dalam penerapannya masyarakat hanya menanam pada saat musim penghujan tiba (Oktober - Februari) setiap tahunnya sambil melakukan pemanfaatan pada usaha tani lainnya misalnya menyadap lontar, beternak, pemeliharaan mente dan lain sebagainya dalam skala usaha tani polipalen saat musim kemarau.

Praktik usaha tani yang tampak pada model Kono di lokasi penelitian dimana jenis tanaman semusim (Jagung dan Padi) lebih mendominasi. Bagi masyarakat setempat budidaya tanaman semusim (Padi dan Jagung) tidak mungkin dilakukan secara terus menerus mengingat input yang dibutuhkan sangat tinggi sehingga dalam penerapannya masyarakat hanya menanam pada saat musim penghujan tiba (Oktober - Februari) setiap tahunnya sambil melakukan pemanfaatan pada usaha tani lainnya misalnya menyadap lontar, beternak, pemeliharaan mente dan lain sebagainya dalam skala usaha tani polipalen saat musim kemarau.

Tabel 4. Komposisi Jenis Tanaman Pada Model Agrosilvicultur Kono Komponen Penyusun

Nama Lokal Nama Binomial Manfaat Tanaman Berkayu :

\begin{tabular}{|c|c|c|c|}
\hline 1 & $\begin{array}{l}\text { Hau meni / } \\
\text { Cendana }\end{array}$ & $\begin{array}{l}\text { Santalum album } \\
\text { Swietenia }\end{array}$ & Konservasi \& Ekonomi \\
\hline 2 & Mahoni & macrophylla L & Konservasi \& Ekonomi \\
\hline 3 & Huek & Eucalyptur alba & Konservasi \& Ekonomi \\
\hline 4 & Атрири & Eucalyptus urophylla & Konservasi \& Ekonomi \\
\hline 5 & Tuak / Lontar & Borassus flabellifer & Konservasi \& Ekonomi \\
\hline 6 & Kiи / Asam & Tamarindus indica & Konservasi \& Ekonomi \\
\hline 7 & $\begin{array}{l}\text { Hau Boela / } \\
\text { Pohon Daun } \\
\text { Кири-Кири }\end{array}$ & Bauhinia purpurea $L$. & Konservasi \& Ekonomi \\
\hline 8 & $\begin{array}{l}\text { Aijao / Cemara } \\
\text { gunung }\end{array}$ & $\begin{array}{l}\text { Casuarina } \\
\text { junghuniana }\end{array}$ & Konservasi \& Ekonomi \\
\hline 9 & Waru & Habiscus & Konservasi \& Ekonomi \\
\hline 10 & Kabesak & macrophyllus & Konservasi \& Ekonomi \\
\hline 11 & Kapok & Vachellia leucophloea & Konservasi \& Ekonomi \\
\hline 12 & Jati & $\begin{array}{l}\text { Ceiba petandra } \\
\text { Tectona grandis }\end{array}$ & Konservasi \& Ekonomi \\
\hline \multicolumn{4}{|c|}{ Tanaman Tahunan : } \\
\hline 1 & Kopi & Coffea arabica & Ekonomi \\
\hline 2 & Manus / Pinang & Areca catechu & Ekonomi \\
\hline 3 & Puah / Sirih & Piter betle & Ekonomi \\
\hline 4 & Uki/ Pisang & Musa Paradisiaca L & Ekonomi \\
\hline 5 & Jambu Mente & $\begin{array}{l}\text { Anacardium } \\
\text { occidentale }\end{array}$ & Ekonomi \\
\hline \multicolumn{4}{|c|}{ Tanaman Semusim : } \\
\hline 1. & Jagung & Zea Mays & Ekonomi \\
\hline 2. & Kacang tanah & Arachis hypogaea & Konservasi \& Ekonomi \\
\hline 3. & Padi & Oryza Sativa & Ekonomi \\
\hline 4. & Porang & Amorphophallus & Ekonomi \\
\hline 5. & Talas & muelleri & Ekonomi \\
\hline 6. & Labu kuning & Colacasia esculenta & Ekonomi \& Konservasi \\
\hline 7. & Uwi & Cucurbita moschata & Ekonomi \\
\hline 8. & Singkong & Dioscorea balcanica & Ekonomi \\
\hline
\end{tabular}




\begin{tabular}{lll}
\hline 9. Ubi jalar & $\begin{array}{c}\text { Manihot utilissima } \\
\text { Ipomea batatas }\end{array}$ & Ekonomi \& Konservasi \\
\hline
\end{tabular}

\subsection{Analisis Kontribusi Ekonomi Masyarakat}

Kontribusi pendapatan yang diperoleh masyarakat dari masing-masing model pengelolaan lahan berbasis agroforestri tradisional di lokasi penelitian disajikan pada Tabel 5 .

Tabel 5. Kontribusi Pendapatan Masyarakat

\begin{tabular}{lccc}
\hline \multirow{2}{*}{ Kriteria Penilaian } & \multicolumn{3}{c}{ Model Agroforestri Tradisional } \\
& Suf & Poan & Kono \\
\hline Pendapatan Usaha Tani $(R p)$ & 5.000 .000 & 7.500 .000 & 2.500 .000 \\
Total Pemasukan RT $(R p)$ & 8.250 .000 & 11.250 .000 & 4.250 .000 \\
Rata-Rata Pemasukan & 825.000 & 1.125 .000 & 425.000 \\
(Rp/KK/Panenan) & $61 \%$ & $67 \%$ & $59 \%$ \\
KPC $(\%)$ & & &
\end{tabular}

Sumber: Agu (2017)

Keterangan :

- $\quad$ Luas Pemanfaatan lahan yang dipilih pada Model Suf seluas $100 \mathrm{Ha}$ dengan jumlah ternak dalam ranch 200 ekor, sedangkan pada model Kono dan Poan dengan luasan rata-rata 0,50 Ha

- Jumlah responden masing-masing Model 10 Orang per model.

Berdasarkan hasil analisis kontribusi pendapatan masyarakat pada tabel 5 ditemukan nilai KPC pada ketiga model agroforestri tradisional yaitu di atas 50\% dimana untuk Suf 61\%, Poan 67\%, dan Kono 59\%. Hal ini menunjukkan bahwa secara kontribusi ketiga model agroforestri tradisional yang ditemukan di lokasi penelitian ini berpeluang untuk dikembangkan atau dipertahankan dengan perlu adanya intervensi intensif dalam hal pengelolaan yang berkelanjutan dengan pertimbangan pada aspek ekologi wilayah, sosial ekonomi serta budaya atau kearifan lokal masyarakat setempat.

\section{Simpulan}

Berdasarkan hasil penelitian disimpulkan bahwa:

1. Terdapat tiga model pengelolaan lahan kering dataran tinggi berbasis agroforestri tradisional yang ditemukan di lokasi penelitian yang didasarkan pada komposisi jenis vegetasi penyusun lahan serta pola tanam yaitu model agrosilvicultur Kono, model agrosilvopasture Poan dan model silvopastural Suf.

2. Analisis kontribusi pendapatan masyarakat diketahui bahwa nilai kontribusi ketiga model agroforestri tradisional yaitu di atas $50 \%$. Artinya bahwa secara kontribusi ketiga model agroforestri tradisional yang ditemukan berpeluang untuk dikembangkan dengan perlu adanya intervensi intensif dalam hal pengelolaan yang berkelanjutan.

3. Upaya penunjang pembangunan kawasan hutan yang berkelanjutan (Sustainable forest management) pada daerah semi-arid maka pemilihan jenis tanaman harus memperhatikan kondisi iklim, faktor topografi dan persyaratan tumbuh serta keadaan sosial ekonomi masyarakat setempat.

\section{Pustaka}

Saba Agu, Yakobus P.E. 2017. Desain Model Pengelolaan Lahan Kering Dataran Tinggi Berbasis Berbasis Agroforestri Tradisional Di Pulau Timor. Tesis UGM. Yogyakarta.

Badan Pusat Statistik (BPS) Kab. TTU 2016. Timor Tengah Utara dalam Angka. Kefamenanu: Badan Pusat Statistik Kabupaten TTU.

Dako, Fransiskus Xaverius. 2010. Strategi Social Forestry Dalam Perencanaan Pengelolaan Hutan Lindung Mutis Timau Kabupaten Timor Tengah Selatan Provinsi Nusa Tenggara Timur. Tesis Pasca Sarjana Fakultas Kehutanan. Universitas Gadjah Mada. Yogyakarta.

Djogo, Tony. 1994. Management of Mountain Watershed and Forest Resources :Agroforestry in Mountain Development. Paper Presented in Chiang Mai on Agroforestry Curriculum.

Gumelar, T. 2014. Analisa Usaha Tani. Jurnal Penelitian Politeknik LPP. Yogyakarta.

Rencana tata ruang dan tata wilayah (RTRW) Kab. TTU tahun 2018-2038. Penetapan Kawasan Strategis Kab. TTU. Nusa Tenggara Timur.

Rencana Pembangunan Jangka Menengah Daerah (RPJMD), 2011. Luas Wilayah Kab. TTU. Nusa Tenggara Timur.

Sabarnurdin, S., Budiadi, dan P. Suryanto, 2011. Agroforestri Untuk Indonesia: Strategi Kelestarian Hutan Dan Kemakmuran. Cakrawala Media, Yogyakarta.

Suradisastra, K. 2001. Konteks Ekologi Kultural Kawasan Timur Indonesia Dalam Optimalisasi Lahan Kering. Deputi Bidang Investasi dan Pembiayaan, Kementerian Percepatan Pembangunan Kawasan Timur Indonesia. Jakarta.

Ukrani, R., dan C.K. Jain, 2010. Agroforestry Sistem and Practices. Oxford Book Company. India. 